\title{
Recurrent Aphthous Ulcers (RAS) and Its Prevalence among People of Punjab
}

\author{
RAHUL SHARMA', ABHISHEK SHARMA ${ }^{* 2}$
}

OBJECTIVE: At times neglected, an oral ulcer is usually benign in nature and resolves spontaneously, howevers, a small proportions of it are malignant in nature.

AIM: To determine the prevalence of recurrent aphthous ulcers (RAS) screened in different locations in the Indian state of Punjab. Material and Methods: over a period of three months, a total of 2245 patients were screened among various camps organized around various states of Punjab using an ADA Type IV examination with recording a detailed family and medical history. Data was analysied using SPPS version 19.0.

RESULTS: 779 patients presented with recurrent aphthous ulceration (34.7\%). Females (413, 53.1\%) were more commonly affected than males $(366,46.9 \%)$ with those being affected in the Patients in the third and fourth decade of their life and this difference was statistically significant. The most factor associated was stress stomatitis seen in 453 patients $(58.2 \%)$. Food consumed was the second common factor related with the condition (121 patients, 15.5\%), closely followed by nutritional deficiency (113 patients, 14.5\%). There were no significant difference seen between any of the factors and the occurrence of RAS in the patients.

CONCLUSION: It was revealed that recurrent aphthous ulceration is a common mucosal disorder in the people of Punjab. Early, proper and prompt diagnosis of the ulcers will help the dental practitioner in providing information to the patient, educate the patient regarding this condition and regarding and management of the condition.

KEYWORDS: Recurrent Aphthous Ulcers, Pain, Stress

\section{INTRODUCTION}

A common complaint among patients, Oral ulcers affect approximately $4 \%$ of people worldwide with $25 \%$ of these ulcers classified as Recurrent Apthous ulcers(RAS), ${ }^{1,2}$ Its origin is derived from the Greek Word, "Apthae" meaning ulceration and clinical manifestations include multiple, small, round, or ovoid ulcers, with circumscribed margins, covered by a yellowish or gray-white fibrinous exudate and surrounded by an erythematous halo, and present first in childhood or adolescence. ${ }^{3}$ These ulcers are associated with intense or moderate pain; and heal in 10-14 days for the more common type and more than 2 weeks for the severe type. Its recurrence occurs in intervals spanning within a year or over several years depending on various factors. ${ }^{4}$

The triggering factors for an episode of RAS is unknown and extensive research in a large patient series identify a range of local, hematological, gastrointestinal, immunologic, genetic, nutritional, allergic, psychological, and medication reactions as the most probable triggers in few patients with RAS. ${ }^{5,6}$ The ulcerative stage lasts for $3-7$ days. The healing stage is identified by the abrupt cessation of pain and the appearance of granulations within the decreasing surface exudate. The remission stage identifies the ulcerfree periods and triggered by some dietary items and occasionally in the premenstrual phase. ${ }^{5}$

These ulcers have a potential to affect the one's quality of life and hence, this present study was undertaken with the aim to assess the prevalence of recurrent aphthous ulcers (RAS) screened in different locations in the Indian state of Punjab.

\section{MATERIALS AND METHODS}

This prospective study included patients screened at various places in the Indian state of Punjab through organization of various dental camps for a period of three months (October 2018December 2018) after obtaining proper ethical clearance and required permissions. The patients were duly informed regarding the confidentiality of their data and was coded to prevent any misuse of the same.

A total of 2245 patients from all age groups were screened using an ADA Type IV examination. Any 
patient with suspected malignant ulcers based on clinical examination were excluded from the study and sent for further diagnosis and confirmation of the lesion.

The aphthous included the minor, major and herpitiform types, which are characterized by recurrence. A detailed family and medical history and history in relation with any habits of tobacco/smoking/alcohol was recorded. Medical history included any systemic disease, association of ulcers with menstrual cycle, any medication, and any associated ulcers involving organs like skin, vagina, eye or joints and the lymph nodes were also examined.

Medication taken for the condition were duly asked and noted. They were also enquired about other independent factors related to the condition and for those diagnosed as having any type of RAS, Were advised to undergo Full blood count (FBC), erythrocyte sedimentation rate (ESR), Rheumatoid factor, serum folate, vitamin B12 and ferritin levels tests. Data was analysed using SPSS version 19.0 and subject to statistical tests (t-test) as described in the results.

\section{RESULTS}

Table 1 is a brief description of the patients screened according to the decades and presence of ulcers. It was observed that of the total of 2245 patients screened, RAS was found in 779 patients (prevalence: $34.7 \%$ ) and the maximum was seen in the third $(22.6 \%)$ and fourth decade $(26.58 \%)$ of life.

\begin{tabular}{|c|c|c|}
\hline $\begin{array}{c}\text { AGE (In } \\
\text { Years) }\end{array}$ & $\begin{array}{c}\text { No. of } \\
\text { Patients }\end{array}$ & $\%$ \\
\hline $1-10$ & 76 & 9.76 \\
\hline $11-20$ & 85 & 10.91 \\
\hline $21-30$ & 176 & 22.60 \\
\hline $31-40$ & 207 & 26.58 \\
\hline $41-50$ & 78 & 10.01 \\
\hline $51-60$ & 76 & 9.76 \\
\hline$>60$ & 81 & 10.38 \\
\hline TOTAL & 779 & 100 \\
\hline
\end{tabular}

Table 1. Presence of RAS among various age groups in the screened population
Gender-wise distribution is seen in table 2 and RAS was seen more in Females $(413,53.1 \%)$ as compared to males $(366,46.9 \%)$ and the presence of RAS according to gender was found out to be statistically significant $(\mathrm{p}=\mathrm{o} .01)$.

\begin{tabular}{|c|c|c|c|}
\hline GENDER & $\begin{array}{c}\text { No. of } \\
\text { Patients }\end{array}$ & $\%$ & P (t-test) \\
\hline Males & 366 & 46.9 & $\begin{array}{c}\text { O.o1* }^{*} \\
\text { (Significant) }\end{array}$ \\
\hline Females & 413 & 53.1 & \\
\hline TOTAL & 779 & 100 & \\
\hline
\end{tabular}

Table 2. Gender-wise distribution of RAS in the study population

Table 3 presents information regarding the factors related to RAS in the present study. Stress was identified as the most common factor, leading to recurrent ulcerations in 453 patients $(58.2 \%)$. Food consumed was the second common factor related with the condition (121 patients, 15.5\%), closely followed by nutritional deficiency (113 patients, $14.5 \%$ ). There were no significant difference seen between any of the factors and the occurrence of RAS in the patients.

\begin{tabular}{|c|c|c|c|}
\hline FACTORS & \multicolumn{1}{c}{$\begin{array}{c}\text { No. of } \\
\text { Patients }\end{array}$} & $\%$ & $\begin{array}{c}\text { P value } \\
\text { (t-test) }\end{array}$ \\
\hline Stress & 453 & 58.2 & NS \\
\hline $\begin{array}{c}\text { Food } \\
\text { consumed }\end{array}$ & 121 & 15.5 & NS \\
\hline $\begin{array}{c}\text { Nutritional } \\
\text { Deficiency }\end{array}$ & 113 & 14.5 & NS \\
\hline $\begin{array}{c}\text { Other } \\
\text { Factors }\end{array}$ & 92 & 11.8 & NS \\
\hline TOTAL & 779 & 100 & NS \\
\hline
\end{tabular}

Table 3. Factors causing RAS in the study population

\section{DISCUSSION}

The present study, with the aim to determine the prevalence of recurrent aphthous ulcers (RAS) in the Indian state of Punjab revealed that the prevalence of RAS in Punjab was 34.7\%, Females were more affected as compared to males with RAS occurring more commonly in the third and fourth decades of life. Stress was identified as the most common factor, leading to recurrent ulcerations in 453 patients $(58.2 \%)$. Food consumed was the second common factor related with the condition (121 patients, 15.5\%), closely 
followed by nutritional deficiency (113 patients, $14.5 \%)$.

RAS is a common oral mucosal condition and has been reported as affecting $20 \%$ of the general population at any time, ${ }^{7,8}$ and the findings of the present study $(34.7 \%)$ is on the higher side as compared to the abovementoned statement. However, Safadi RA reported a prevalence of $78 \%$ in the Jordanian population, which is higher in comparison to the findings of the present study. ${ }^{9}$ In disagreement to the results of the present study, Bhatanagar $\mathrm{P}$ et al.(1.53\%), ${ }^{10}$ Patil S et al. ${ }^{11}$ $(21.7 \%)$ and Davatchi F et al. (25.2\%). ${ }^{12}$

The etiopathogenesis of RAS is still unclear, although various agents have been identified for its causation. As per Shohat-Zabarski R, ${ }^{13}$ Genetic factors are likely to cause RAS in patients, and more than $40 \%$ of affected individuals have first degree relatives with a diagnosis of RAS. Another theory suggests an immunologic basis for RAS while recently, a cross reactivity between a streptococcal heat shock protein (hsp) and the human mitochondria hsp in the oral mucosa, which may lead to a T-cell mediated response to antigens is stated. ${ }^{14}$ There also seems to be a negative association between smoking and RAS although some patients report the onset of oral ulcers after smoking cessation. ${ }^{15}$ While stress was found to be a common cause for RAS $(58.2 \%)$ and was supported by Patil S et $\mathrm{al}^{11}{ }^{11}$ there is little substantive evidence to link stress to RAS. ${ }^{16}$

In the present study, Females (53.1\%) were more frequently affected than males (46.9\%) and this difference was observed to be statistically significant $(\mathrm{p}=\mathrm{0.01})$ and are in agreement to Patil S et al. ${ }^{11}$ and Safadi RA. ${ }^{9}$ The reason for such findings can be that females are more prone to stress and emotional situations which can affect their immune response along with hormonal changes during pregnancy and menstruation. ${ }^{11}$

\section{CONCLUSION}

The present students documents an increased prevalence of RAS of the population in Punjab and efforts should be directed to screen such patients. Also, awareness campaigns are also advised to motivate people to get their oral check-up done at regular intervals for any such potential problem arising in their oral cavity.

\section{REFERENCES}

1. Shulman JD, Beach MM, Rivera-Hidalgo F. The prevalence of oral mucosal lesions in U.S. adults: data from the Third National Health and Nutrition Examination Survey, 1988-1994. J Am Dent Assoc. 2004;135:1279-86.

2. Patil S, Reddy SN, Maheshwari S, Khandelwal S, Shruthi D, Doni B. Prevalence of recurrent aphthous ulceration in the Indian Population. J Clin Exp Dent. 2014;6(1):e36-40.

3. Jurge S, Kuffer R, Scully C, Porter SR. Mucosal disease series. Number VI. Recurrent aphthous stomatitis. Oral Dis. 2006;12:1-21.

4. Ship JA, Chavez EM, Doerr PA, Henson BS, Sarmadi M. Recurrent Aphthous Stomatitis. Quintessence Int. 2000;31:95-112.

5. Rajmane YR, Ashwinirani S R, Suragimath G, Nayak A, Rajmane VS, Lohana M. Prevalence of recurrent aphthous stomatitis in western population of Maharashtra, India. J Oral Res Rev 2017;9:25-8.

6. Rogers RS 3rd. Recurrent aphthous stomatitis: Clinical characteristics and associated systemic disorders. Semin Cutan Med Surg 1997;16:278-83 7. Field EA, Allan RB. Review article: oral ulceration - aetiopathogenesis, clinical diagnosis and management in the gastrointestinal clinic. Aliment Pharmacol Ther 2003; 18: 949-62.

8. Rennie JS, Reade PC, Hay KD, et al. Recurrent aphthous stomatitis. Br Dent J 1985; 159: 361-7.

9. Safadi RA. Prevalence of recurrent aphthous ulceration in Jordanian dental patients. BMC Oral Health. 2009;9:31.

10. Bhatnagar P, Rai S, Bhatnagar G, Kaur M, Goel $S$, Prabhat M. Prevalence study of oral mucosal lesions, mucosal variants, and treatment required for patients reporting to a dental school in North India: In accordance with WHO guidelines. J Family Community Med. 2013;20:41-8.

11. Patil S, Reddy SN, Maheshwari S, Khandelwal S, Shruthi D, Doni B. Prevalence of recurrent aphthous ulceration in the Indian Population. J Clin Exp Dent. 2014;6(1):e36-40.

12. Davatchi F, Tehrani-Banihashemi A, Jamshidi AR, Chams-Davatchi C, Gholami J, Moradi M, et al. The prevalence of oral aphthosis in a normal population in Iran: a WHO-ILAR COPCORD study. Arch Iran Med. 2008;11:207-9.

13. Shohat-Zabarski R, Kalderon S, Klein T, et al. Close association of HLA-B 51 in persons with recurrent aphthous stomatitis. Oral Surg Oral Med Oral Pathol 1992; 74: 455-8. 
14. Zain RB. Oral recurrent aphthous ulcers/stomatitis: prevalence in Malaysia and an epidemiological update. J Oral Sci. 2000;42:15-9. 15. Dorsey C. More observations on relief of aphthous stomatitis on resumption of cigarette smoking. Calif Med 1964; 101:377-8.
16. Pedersen A. Psychologic stress and recurrent aphthous ulceration. J Oral Pathol Med 1989; 18: 119-22.
Cite this article as:

Sharma R, Sharma A. Recurrent Aphthous Ulcers (RAS) and Its Prevalence among People of Punjab. Int Healthc Res J. 2019;2(12):309-312. doi: 10.26440/IHRJ/0212.03.521060

Source of support: Nil, Conflict of interest: None declared

\section{AUTHOR AFFILIATIONS:}

1. BDS, Private Practioner, Nawanshehar, Punjab, India

2. Intern, Swami Devi Dyal Hospital and Dental College, Barwala, Haryana, India

${ }^{*}$ Corresponding Author:

Dr. Abhishek Sharma

46-C, Pinjore Apartments

Pinjore 134104
For article enquiry/author contact details, e-mail at: editor.ihrj@gmail.com,editor@ihrjournal.com 